THE EXPERIENCE OF INJUSTICE 


\section{NEW DIRECTIONS IN CRITICAL THEORY}

Amy Allen, General Editor

New Directions in Critical Theory presents outstanding classic and contemporary texts in the tradition of critical social theory, broadly construed. The series aims to renew and advance the program of critical social theory, with a particular focus on theorizing contemporary struggles around gender, race, sexuality, class, and globalization and their complex interconnections.

For a complete list of books in this series, see pages 273-274 


\title{
The Experience of Injustice
}

A THEORY OF RECOGNITION

\section{Emmanuel Renault}

TRANSLATED BY

Richard A. Lynch

\author{
$\$$ \\ Columbia University Press \\ New York
}




\author{
Columbia University Press \\ Publishers Since 1893 \\ New York Chichester, West Sussex \\ cup.columbia.edu \\ L'expérience de l'injustice \\ Reconnaissance et clinique de l'injustice \\ by Emmanuel Renault \\ (c) Editions La Découverte, Paris, France, 2004. \\ Copyright (C) 2019 Columbia University Press \\ All rights reserved
}

Cataloging-in-Publication Data is available from the Library of Congress.

ISBN 978-0-231-17706-1 (cloth)

ISBN 978-0-231-54898-4 (e-book)

Columbia University Press books are printed on permanent and durable acid-free paper.

Printed in the United States of America

Cover design: Milenda Nan Ok Lee

Cover photo: Nikolas Georgiou / () Alamy 